\title{
Penance in the Perspective of the Theology of the Body*
}

The relation between the issues of penance and the theology of the body results not only from the time convergence of two documents: the exhortation Reconciliatio et paenitentia (1984) and the Wednesday catechesis devoted to the ethical sense of the sacrament of matrimony (1979-1984). The common time of the creation of these documents is a sign of the perspicacity of John Paul II who, in the beginning of the 80s of the previous century, saw the necessity for a new way of speaking about both, the Catholic theology of marriage and human sexuality as well as about broadly understood penance, including sacramental confession.

The novelty of the papal catechesis on the theology of the body consisted in the fact that, presenting the biblical grounds for God's covenant with people, John Paul II was not afraid of the language of reason, which reads the language of the human body ${ }^{1}$. This perspective is particularly visible in the second part of the catechesis, where biblical-personalistic reasoning is proposed in the context of the marriage vows. It is juxtaposed, on one hand - with the lust of the flesh, and on the other - with the content of the Song of Songs. All this leads to a beautiful contemplation regarding the prayer of a husband and wife.

In this context, the language of liturgy becomes the body language of the husband and wife, and the sacramental sign - the most effective inspiration for their conversion and penance. By receiving the sacrament of matrimony, the husband and wife open themselves "to the encounter of a great 'mysterium' in order to transfer the light of that 'mysterium', the light of truth and beauty expressed in the language of liturgy, into the 'body language,' translating it to the 'praxis' language of love, fidelity and conjugal honesty: to the ethos 
of hope, which is rooted in the 'redemption of the body' (Rom 8:23). On this path, marriage life becomes liturgy, in a certain sense."

From this liturgy we cannot exclude any of the meanings of penance which function in everyday pastoral language: the virtue of penance, penitential practices (prayer, fasting and almsgiving) and the sacrament of penance. In Reconciliatio et paenitentia John Paul II very precisely defines various meanings of this term. Penance is here both, "the internal transformation of the heart occurring thanks to the influence of the Word of God and in the perspective of the kingdom of God" (cf. Mt 4:17; Mk 1:15), and "the transformation of life in accordance with the transformation of the heart," which becomes fulfilled in penitential practices (cf. Lk 3:8). As a consequence, penance takes the form of ascetism, "of everyday effort of a human, supported by God's grace, to lose one's life for Christ (cf. Mt 16:24-26; Mk 8:34-36; Lk 9:23-25); in order to put off the old man and put on the new one (cf. Eph 4:23 et seq.) in order to overcome in one's self what if of the flesh so that what is spiritual, prevails (cf. 1Cor 3:1-20)."”

Penance which, in the understanding of John Paul II, is conversion, which goes from the heart to actions, i.e. to the concrete situations of Christian life, becomes the basic topic of the theology of the body, by anchoring it in the human heart. In the Wednesday catechesis John Paul II devoted much contemplation to this conversion, in the context of both: the lust of the flesh and his call for purity. This refers to the marital ethos and to marital spirituality, which, by the way, cannot be imagined without the sacrament of penance. In the present article we are going to indicate three significant elements which connect penance with the theology of the body: (1) integrity of life in the body, although not according to the body (2) the theological understanding of lust and (3) the issue of guilt and of confessing sins. This way we want to confirm the integrity of penance as a virtue, of penitential practices and of the sacrament of penance.

\section{Life in the Flesh vs. Life according to the flesh}

The papal theology of the body revealed the richness of the biblical understanding of the body, which has nothing to do with Manichaeism, i.e. with accusing the human heart of lust which cannot be overcome. This is important in times when Christian penance is being exposed to criticism. According to critics,

2 John Paul II, Mężczyzna i niewiasta stworzył ich. Odkupienie ciała a sakramentalność małżeństwa, Città del Vaticano 1986, 457.

3 John Paul II, Reconciliatio et paenitentia, 4. 
it should break free not only from traces of Manichaeism, but also from any effort of moral formation, especially in the area of human sexuality. For several dozen years the criticism is being strengthened by the false hermeneutics of masters of suspicion (Marx, Freud and Nietzsche), who have questioned the ability of the human heart to oppose to lust in general ${ }^{4}$.

Many critics of Christian ascetism have used St. Paul's critical attitude towards the body as their argument. Studies related to St. Paul's thought, which had been being carried out for a long time, demonstrated that his description of the human body cannot be treated as a study of nature, nor what is more important - be isolated from evaluation assuming the biblical truth on the creation and redemption of the human body. John Paul II writes in a straightforward way that "Paul's description of the body corresponds (...) to the spiritual attitude of 'honor' for the human body, honor which the body deserves due to the 'holiness' (cf. 1Tes 4:3-8), originating from the mysteries of creation and redemption. This description is equally distant from the Manichaean contempt for the body as well as from various manifestations of the naturalist 'worship of the body'."

St. Paul, who was raised in a Jewish family inhabiting the diaspora, underlined his association with Judaism, although he used the terminology taken from philosophic-spiritual trends which were contemporary to him. While remaining a Jew, he used Greek notions: sarx, soma and pneuma, in order to convey the Christian message. By pneuma Paul expresses the openness of a person to the Holy Spirit. On one hand the human spirit is not radically separated from the Holy Spirit, and on the other, the Holy Spirit induces a person not only to prayer (cf. Rom 8:26-27), but also to love resulting in effects which have been listed in Gal 5 and 1Cor 13. They may be treated as the fruit of penance. Opposing sarx against pneuma in a person is, therefore, senseful only as far as sarx determines what is heavenly, what is due to God and open to Him.

Sarx and pneuma indicate two ways of human existence - the bodily one, which is enclosed in matter and human psyche, and the heavenly one, which is open to the Holy Spirit. This does not mean that there are two spheres, substances or human qualities which are impossible to cross. A person is one holistic being who is able to believe in Jesus Christ. Faith opens him or her to the action of the Holy Spirit, effectuating God's image and resemblance in that person. The tension between life in the body (in the world) and life in Christ should be 
explained by the fact that Paul never discusses natural life in the body without faith in Jesus Christ, which inspires to conversion 6 .

Besides the word sarx, Paul also uses soma to define the body. The meaning of this word is close to the notion of a person. This however does not refer to a person understood in an individualist way, closed within him- or herself. Soma expresses relationships towards both, one's own self, as well as others. The community sense of the word soma is expressed in the ability to harmonious cooperation of various parts of the organism. St. Paul is the author of the theology of Christ's Body, which is complemented by the Church, as the Mystic Body of Christ. Participation in Christ's Body consists in living the Body of the Lord, transforming one's own body in such a way so that this body becomes similar to the spiritual body, offered by the Lord?

Here we can find the source of Christian penance, as continuous conversion, spiritual renewal and being capable of the Christian ability to look at one's self through the eyes of the Savior. Penance, as the internal transformation of the heart under the influence of God's Word and in the perspective of God's kingdom, assumes maintaining one's own body in holiness and honor (cf. 1 Tes 4:4). Only then Christian existence which, after all, occurs in the body, does not lead to sin. This has been precisely captured in the Epistle to the Galatians: "I no longer live, but Christ lives in me. The life I now live in the body, I live by faith in the Son of God" (Gal 2:20). Here Paul is not describing what is happening with his body in the material sense. He is writing about a person living in the world and subjected to the challenges of this world ${ }^{8}$.

Life in the body has to, therefore, be perceived as the possibility to serve God, people and the community. The positive role of the body in such service cannot obscure the risk of treating the body as an object, i.e. living according to the body. In Paul's texts this last formula also takes the form of being bodily. It is that way in 1Cor 3:1-3 where Paul is writing to the Corinthians that they were and they are bodily, which manifests itself in their jealousy and quarreling. Their life according to the body takes on reprehensible sense.

In 2Cor 5:16 Paul states that "from now on we regard no one from a worldly point of view (i.e. according to the body - translator's note). Though we once regarded Christ in this way, we do so no longer." The apostle opposes to those

6 Cf. I. Mroczkowski, Osoba i cielesność. Moralne aspekty teologii ciała, Warsaw 2008, 129-136.

7 Cf. Ibid., 271.

8 Cf. A. Sand, Der Begriff „Fleisch” in den Paulinischen Hauptbriefen, Regensburg 1967, 166. 
who take pride in what is seen (what is external - translator's note) (cf. 2Cor 5:12b), those who preach themselves (cf. 2Cor 4:5), those who wage war as the world does (according to the body - translator's note) (cf. 2Cor 10:3). The apostle defends himself from those who accuse him of acting in a worldly way - according to the body. He writes the following: "though we live in the world (i.e. the body - translator's note), we do not wage war as the world does (i.e. according to the body - translator's note). The weapons we fight with are not the weapons of the world. On the contrary, they have divine power to demolish strongholds" (2Cor 10:3-4). Worldly conduct and fighting using worldly methods are those of a person who does not submit to conversion. This conduct and these methods should change in case of persons who belong to Christ (cf. 2Cor 10:7) ${ }^{9}$. It is impossible to imagine such a transformation without constant conversion which manifests itself in both, the virtue of penance and in its particular acts.

Therefore, using Paul's formulas of life in the body and life according to the body for the purpose of demonstrating the connection between the theology of the body and the virtue of penance, one can say that "it is in the heart where the struggle between 'life according to the body' and 'life according to the Spirit' takes place. (...). In human's current condition, with the hereditary sinfulness, the body alone shows its weakness, insufficiency and it succumbs, if it is not internally strengthened to fulfill 'what the Spirit wills'." 10 . Acting according to the body is that of a person who trusts him- or herself and the world more than God. By forgetting about the dependence on the Creator, a worldly person makes him- or herself - and frequently his or her bodily needs - the only criterion of conduct.

It is not surprising, therefore, that such a person associates penance with needless mortification, psychologically suspicious ascetism, resentment. The theology of the body reveals the most important sources of spiritual power of a human who wants to remain on the path of constant conversion. This person's everyday spiritual sensitivity cannot forget that it is the Holy Spirit who has poured out God's love into our hearts (cf. Rom 5:5) and our body is a temple of the Holy Spirit (cf. 1 Cor 6:19). The human body was created by God from the dust of the ground, but the Son of God accepted it and used it to carry out the work of salvation. God's Word coming from the Father became a real inspiration of our transformation, because we all have been saved not due to Platonic love, but by the death and resurrection of Jesus Christ.

9 Cf. I. Mroczkowski, Osoba..., op. cit., $140 \mathrm{f}$.

10 Cf. Jan Paweł II, Mężczyzną..., op. cit., 206. 


\section{Penance And Lust}

Christian hope, which is the nourishment for Christian penance, cannot omit these impulses of human nature which induce human to sin. Omitting them would not only deny the realism of human nature, but it would also expose Christian penance to ineffectiveness. In the fragment 5:16 of the Epistle to the Galatians, St. Paul encourages to act according to the Spirit and not to fulfill the desires of the body. It is necessary to "put off your old self, which is being corrupted by its deceitful desires (...) and to put on the new self, created to be like God in true righteousness and holiness" (Eph 4:22-24).

A person grafted in Jesus Christ is no longer a slave of lust, but this does not mean that such a person is not exposed to its influence. We find a testimony of a struggle between a bodily person and a freed one in the seventh chapter of the Epistle to the Romans ${ }^{11}$. The author thanks God that through Jesus Christ He gave people the possibility to overcome the sin which inhabits them. It is not enough to just become familiar with the law; it is necessary to remain in Christ.

In the New Testament the word lust (epithymia) ${ }^{12} \mathrm{~d}$ oes not only signify bodily, or simply sexual desire. St. Mark mentions the worries of this life, the deceitfulness of wealth and the desires for other things (Mk 4:19). We can find a synthetic utterance on threefold lust in St. John's first Epistle: "For everything in the world - the lust of the flesh, the lust of the eyes, and the pride of lifecomes not from the Father but from the world. The world and its desires pass away, but whoever does the will of God lives forever" (1J 2:16-17).

John's words do not deny the spirit of St. Paul's Epistles. Both his sarks, as well as soma do not define some part of human, but they express religious references which cannot be identified with sensuality in the ontological sense ${ }^{13}$. The human heart, and not his or her body, is the place where the struggle between life according to the body and life according to the Spirit takes place. In the history of theology it happened that the area of this struggle was placed in sensuality and carnality. All the gnosticizing and neoplatonic interpretations too broadly identified human bodily imperfection with imperfection towards

11 Cf. L. Cerfaux, Une lecture de l'Épitre aux Romains, Tournai 1947; S. Lyonnet, La storia della salvezza nella Lettera ai Romani, Napoli 1966, 97-166.

12 Cf. K. Büchsel, Epithymia, in: Theologisches Wörterbuch zum Neuen Testament, vol. 4, 593-602.

13 Cf. K. Rahner, Zum theologischen Begriff der Konkupiscenz, in: Id., Schriften zur Theologie, vol. 1, Einsiedeln 1958, 385, footnote 1. 
God. Until today it is a matter of dispute, to what extent St. Augustin's thought succumbed to that influence ${ }^{14}$.

The Council of Trent ruled the following: "And referring to lust, which the Apostle sometimes refers to as 'sin' (Rom 6:12 et seq.), the Holy Council declares that the Catholic Church never understood in such a way as if in the reborn (people) it was a real and proper sin, but (it is called that way) because it is a remnant of sin and it induces to $\sin .{ }^{.15}$ This utterance may be fully understood after in-depth interpretation of lust in the context of the adequate notion of the subject of human action. One of the theologians who undertook this task was K. Rahner who differentiated lust in a broad, a narrow and a theological sense ${ }^{16}$.

In the broad sense, lust is realized as conscious reactivity of our body. Biological-mental reactions of the organism manifest themselves almost spontaneously in the form of reflexes which should be subjected to the processing of the subject of action. Here we can recall Wojtyła's perspective on human reflexes. He treated them as the area of the earliest improvements, including among them instinct reactions which become visible in human urges ${ }^{17}$.

When that reactive dynamics of the body is included in the self-determination of a person, we encounter lust in a narrower sense. It is based on the dynamics of nature and it directs a person towards particular good. In awareness it usually takes the form of a spontaneous act ${ }^{18}$. It is most frequently expressed in a person's feeling. According to Wojtyła, being able to feel is the most elementary manifestation of human psyche and, at the same time, the most psychical reflex of the human somatic realm. It develops and becomes expressed through a richness of human feelings, moods and emotions. The lust (understood in the narrower sense) related to them may be used for both, good and bad.

The integration of the rich world of feelings in the structure of a person, is the great art of life. Therefore we talk about human internal difficulty during the synthesis of human self-agency and subjectivity. Difficulty is proof of the tension between the maturity of the human subject and his or her bonds with the world which are anchored in carnality. Human, as a person, always stands before the task of extracting all the possibilities from his or her nature.

14 Cf. X. Léon-Dufour, Grâce e libre arbitre chez S. Augustin, "Recherches de Science Religieuse" 33(1946), 129-163.

15 BF, V, 50.

16 K. Rahner, art. cit., 388-400.

17 Cf. K. Wojtyła, Osoba, czyn oraz inne studia antropologiczne, Lublin 2000, 254.

18 Cf. K. Rahner, art. cit., 389. 
Rahner claims that there is always tension between who a person is and who he or she should be. A person will never fulfill his or her nature fully on Earth $^{19}$. In human there is a lot of what is impersonal, submerged in the darkness of instincts and subconsciousness. This dualism between nature - understood as fulfilling all the possibilities of a human being - and the personal implementation of the subject of action (agent) is referred to by Rahner as lust in the theological sense ${ }^{20}$. The biblical description of sin mentions lust as a result of sin. Shame and fear became its manifestation (cf. Gen 3:7-8).

John Paul II points out that the biblical-theological meaning of lust cannot be identified with the meaning we come across in contemporary psychological approaches. The biblical lust indicates the condition of the human spirit. Along with sin, "the flesh desires what is contrary to the Spirit, and the Spirit what is contrary to the flesh" (Gal 5:17). The result of this is a lack of personal integrity which has been concisely defined by St. John as the lust of the flesh, the lust of the eyes, and the pride of life (cf. 1J 2:16). John Paul II compares these areas of lust to those which were described by the hereinabove mentioned masters of suspicion: Freud, Nietzsche and Marx. "The judgement and accusation of the human heart, in the Nietzschean hermeneutics, in a certain sense, corresponds to all that has been referred to in the biblical language as «the pride of life,» in Marx's hermeneutics - to what has been referred to as «the lust of the eyes,» and in Freud's hermeneutics - to what has been referred to as the «the lust of the flesh»." ${ }^{21}$

This convergence should not surprise us. In the history of ethics and morality, the most frequently mentioned dimensions of human existence which required penance, were greed, impurity and pride. Greed was most frequently treated by controlling egoism, impurity - by the virtue of purity, whereas pride was confronted with the individual and the social truth referring to a human. Moreover, we cannot forget that the convergence between the biblical truth referring to lust and the contemporary hermeneutics of evil is not full. It is possible to compare its areas, but their anthropological setting is different, not to mention the ways of dealing with lust. In the Bible, "lust does not constitute the basic and, in a certain sense, the only and final criterion of anthropology ad ethics." 22

In this context, the Christian understanding of penance assumes not only the criticism of the reductionist statements of the masters of suspicion, but it

19 Cf. Ibid., 393.

20 Cf. Ibid., 400.

21 John Paul II, Mężczyzną..., op. cit., 184.

22 Ibid. 
enters into dispute with the post-modern escape from moral-spiritual effort, on which the virtue of penance is developed. In the Christian understanding, penance is a positive response to the call to fulfill the image and resemblance to God in human. Even if the human body desires what is contrary to the Spirit, it never loses its connection with the human spiritual center. In the center of personal subjectivity, reason becomes opened to faith, freedom is nourished with hope, and the thirst of love meets God, who is love. Therefore, it is impossible to imagine Christian penance without faith and prayer which accompanies it, without hope which brings the conviction that a human is capable of more than is suggested by his or her bodily lust, and without love which - in the penitential sense - is accompanied by the practice of mercy. In this sense, the basic structure of the virtue of penance is based on faith, hope and love which are accompanied by three penitential practices: prayer, fasting and almsgiving.

\section{Guilt and Confession of Sins}

The connection between the theology of the body and penance, identified in overcoming lust, cannot ignore the problem of a person's guilt and responsibility. By nature, the human is called to take responsibility for both, his or her own identity as well as for others. Only in the perspective of guilt as an obligation may we ask about the sense of guilt as a trespass. Ricoeur puts it the following way: "guilt is not the synonym of a trespass. (...) guilt - when considered separately - may be traced in various directions: towards ethical-legal reflection on the relationship of punishability to responsibility; towards an ethical-religious reflection on delicate and scrupulous conscience; and finally - towards a mental-religious reflection on the hell of a blamed and sentenced awareness." ${ }^{23}$

All the directions of analyzing guilt listed by Ricoeur may be explicated theologically. The human, as a being created in God's image and resemblance, is to the same extent called to the implementation of his or her own freedom as well as he or she is aware of the gravity of that obligation. Every time we move away from God because of our sin results in the fact that our obligation (as debitum) becomes infeasible without Christ. People uncritically search for ways of self-justification, the example of which is the contemporary culture of self-justifications and - as a consequence - acceptance of sin. 
Exit from a situation of guilt can be neither a denial of the theological dimension of guilt, nor an attempt to reduce guilt to morbid states of consciousness. From the Christian perspective of redemption, so important for understanding penance, especially in its sacramental act of confession, human guilt fits between the redeemed condition of a person and the fearful way of its implementation, resulting from the consequences of birth-sin. Guilt, as debitum, is an existential experience of a redeemed person who, believing Jesus Christ, not only undertakes some indeterminate option of transforming his or her life, but wants to give a new form to his or her life. This giving of a form is, according to St. Paul, a new existence in Christ, which engages both, a Christian's conscience, as well as living theological virtues and sacraments. Only in this sense, the human debitum, what a human owes to God, to him- or herself and to other people, has a chance to be implemented ${ }^{24}$.

The sense of obligation understood this way places a person before the choice which is carried out in the same way through the basic decision of choosing God as well as specific choices of the human conscience. From a Christian point of view, conscience appears to be the existential ability to responsibly undertake obligation. In this sense it may be compared to the most hidden center and sanctuary of a person, in which this person remains alone with $\mathrm{God}^{25}$. The voice of God, resounding in that sanctuary, may be recognized by the human mind collaborating with human emotional intelligence.

In the conscience, which is subject to the process of development and education, a person may realize the insufficiency of fulfilling his or her own obligation. Jesus mentioned the fruit by which one can recognize the nature of a tree (cf. Mt 7:17-19). St. Paul lists catalogues of virtues and faults (cf. Rom 6:20-23.7:4 et seq.; Gal 5:19-22). If, therefore, guilt is some fulfilled internality of $\sin ^{26}$, then the good fruit, moral skills and moral ascetism constitute milestones of Christian penance. They cannot, however, be treated in the quantitative sense, or, the more so, an external one. There should be a readiness for conversion which facilitates confessing sins. The same way as guilt is the fulfilled internality of sin, penance requires admitting sin and confessing it before God. This is a moment of a degree of internalizing sin which touches the grace of forgiveness. The psalmists of the Old Testament knew perfectly well the power of such a confession: "For I know my transgressions, and my sin is always before me. Against you, you only, have I sinned and done what is evil in your sight" (Ps 50:5-6).

25

26 Cf. P. Ricoeur, op. cit., 136. 
The confession of sins is a moment of connection between two elements which are important for Christian penance: the ability to assess the gravity of sin through conscience and becoming opened to new life. This way it is possible to avoid the curse of blamed awareness which becomes easily transformed in either scrupulosity or rebellion. New life in Christ is nourished by Jesus's obedience which became love to the end. The essence of penance, which builds Christian identity this way, is not so much trusting one's own self, but "clothing one's self with Christ" (cf. Rom 13:14).

In such a view of penance, there is no confusion of the neurotic sense of guilt with the obedience to orders and prohibitions. In the history of moral theology it appeared that the fight against sin was limited to exercising orders and prohibitions. Sometimes the psychological conditions for human development were omitted and attention was not always paid to a false sense of guilt. The effects of that included false conscience, perfectionism or reducing penance to obeying regulations. Penance was accompanied by excessive pessimism and succumbing to false sense of guilt.

Finally, Christian penance, which is indispensable for fulfilling what has become the obligation of a Christian, consists in not so much fulfilling the law, but in carrying out love. Christian conscience is not only a judge, but also a witness of God's voice and a guardian of human existence. Human fate becomes the path of a repentant person who confesses his or her sins and, promising to be better, expresses hope for the forgiveness of his or her trespass. The psalmist had put it perfectly: "Then I acknowledged my sin to you and did not cover up my iniquity. I said, 'I will confess my transgressions to the Lord.' And you forgave the guilt of my sin" (Ps 31:5). In consequence, experiencing guilt does not lead to a self-propelled reel of fear. God's grace bestows a person more than his or her sin impoverished him or her (cf. Rom 5:20).

This way the confession of sins, the Christian manifestation of which is sacramental confession, crowns the path of penance. It includes both, the virtue of penance which, from the perspective of the theology of the body, consists in living in the body, although not according to the body. It does not omit the realism of the threefold lust, opposing it with concrete forms of ascetism (penitential practices) and it finds freshness of the spirit in the Christian sacrament of penance. This way, the Christian practice of penance, as a virtue, of penitential practices and of the sacramental confession of sins, confirms the realism of the theology of the body. 